\title{
ANCIENT EGYPT AND THE OTHER
}

Sakkie Cornelius

Ancient Studies

University of Stellenbosch

\begin{abstract}
Texts and images are used to look at the way the ancient Egyptians perceived and treated 'the other' (their neighbours and foreigners such as the Asians, Kushites and Libyans). Were they treated with dignity? According to the Egyptian world view, Egypt was the centre of the world and the foreign countries were seen as the periphery. Egypt stood for order and the vile foreigners for chaos. The foreigners had to be controlled by the pharaoh who conquered the foreign lands, which also had to pay tribute. This article devotes more attention to the Kushites, who were described as wretched and were physically mistreated. On the other hand, there are also examples of Egyptians interacting with foreigners in a more positive fashion. But in the end not much dignity was accorded to 'the other'.
\end{abstract}

Key Words: Egypt, Human Dignity, Foreigners, Xenophobia

\section{Introduction}

During May 2008, South Africans and the whole world were shocked by the xenophobic attacks on foreigners living in this country. ${ }^{1}$ In the same year the Alexander von HumboldtStiftung Kolleg devoted itself to the theme of 'Human dignity in Africa', looking at matters such as koinonía, dignitas, or to use the African term, ubuntu or 'humanness'. 'Where is ubuntu when Africans attack and kill fellow Africans? How did Africans treat other Africans in the past and for that matter in the very distant past (and in view of the fact that Africa is the cradle of humankind)? Were they treated with dignity or not? This article looks at the way that 'the other', 3 foreigners, but also foreigners resident in Egypt, were perceived and treated by the Egyptians at the time of the pharaohs (ca. 3000-300 BCE). The emphasis here will be on the period 'when Egypt ruled the world', that is under the

1 For a discussion of these events cf. inter alia the report http://www.hsrc.ac.za/Document-2994.phtml. Further

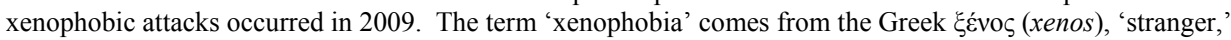
'foreigner' and póßos (phobos), 'fear', i.e. 'fear of others', 'fear of strangers', but is mostly understood as 'dislike/hatred of others' (cf. Allen (1990) 'a deep antipathy to foreigners').

2 This refers to the individual in his or her several relationships with others, as in the maxim umuntu ngumuntu ngabantu (a person is a person through (other) persons) (cf. Louw, n.d.; Van der Merwe, 1996). In contrast to ubuntu as 'humanness', there is 'otherness' (French term altérite).

3 For a theoretical discussion of 'the other' with regard to ancient Greece (as an example of another ancient civilization) cf. Sundermeier (1992); Cartledge (1993); also Coleman \& Walz (1997)); for Mesopotamia see Bahrani (2006); Haas (1980); Pongratz-Leisten (2001) and Van Soldt, Kalvelagen \& Katz (2005).

4 For an overview of the history of pharaonic Egypt cf. the standard work by Shaw (2000). On foreigners in Egypt and Egypt's relations with foreigners see the classic study by Eduard Meyer (1913); also Assmann (1996); Booth (2005); Bresciani (1997); Forbes (2005); Gordon (in OEAE, 2001, 1:544ff.); Haring (2005); Helck (1964 and in Ldت̈, 1977, II:306-310); Leahy (1995); Loprieno (1988); O’Connor (2003); O’Connor \& Quirke (2003); Poo (2005); Schneider (2003, 2010); Smith (in OEAE, 2001, 3:27ff., 111ff.); Vittmann (2003). On the ideology of foreigners cf. also Liverani (1990). 
warrior pharaohs of the New Kingdom dynasties 18 and 19 ca. 1500-1100 BCE. ${ }^{5}$ An examination of the issue of 'the other' in that great ancient African civilization called pharaonic Egypt could be seen as undertaking a 'case study' of how Africans treated other Africans in the past. ${ }^{6}$ This contribution takes an historical perspective, more precisely an ancient historical one, dealing with ancient texts and ancient visual images (iconography) from the discipline of Egyptology.

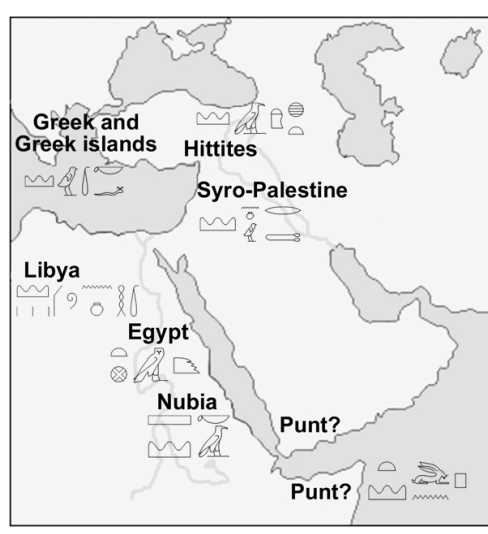

Fig. 1: Egypt and its neighbours (I Cornelius \& LC Swanepoel)

'Egypt', our word for the civilization which developed on the banks of the Nile, comes from Latin (Aegyptos) and Greek. ${ }^{8}$ It is quite ironic that a word from foreign languages used by the later conquerors of Egypt is used to describe this civilization. The ancient Egyptians themselves called their land Kemet (Coptic Keme, Kheme), as written in hieroglyphs (see Figure 1 ). Kemet is the origin of our words for 'alchemy' or 'chemistry' which came to us via the Arabic during the Middle Ages. It literally means Black Land, referring to the fertile soil after the annual inundation. It has to be kept in mind that a three-dimensional phenomenon is presented on a flat sarcophagus cover. ${ }^{9}$ Encircling everything like an arch is a woman - this is the sky goddess, Nut.

\section{Egyptians on Egypt}

How did the ancient Egyptians perceive and see the world (Allen, 2003) and their place in it? The Egyptians saw their country as the country 'as such' (Otto in $L d \ddot{A}, 1977, \mathrm{I}: 76)$. A unique representation of the world appears on the lid of the sarcophagus of Wereshnefer from Saqqarah (Metropolitan Museum of Art 14.7.1; photo in Forman \& Quirke, 1996:136) from the early Ptolemaic period ( $3^{\text {rd }}$ century BCE) (Allen, 2003, Fig. 2.2; Keel, 1977: Abb. 33) (see Figure 2). It is like a map of the world, but because of the mythological elements (the cosmic phenomena were considered divine beings!) this is not really a cartographical document. ${ }^{10}$ Heaven and earth are shown in this complex representation, which is quite confusing to the 'Occidental' mind.

5 For the relations between Egypt and other nations such as the Assyrians and the Greeks in the first millennium BCE, cf. Vittmann (2003).

6 The whole issue of the resident alien (ger) in the Hebrew Bible (Old Testament) is a totally different matter which will not be dealt with here; cf. Fried (2008) and Zehnder (2005).

7 As this article is intended for readers unfamiliar with ancient Egypt, there are some oversimplifications and descriptions for which the Egyptologists should forgive the author. For the same reason a simplified form of writing foreign words is used.

8 The Greek goes back to the Egyptian Khut-ka-Ptah ('the mansion of the ka (spirit) of the god Ptah'), that is Memphis, Akkadian Khikuptakh (cf. Otto in Ld̈̈, 1977, I:77 and Ringgren in TWAT, 1984, IV:1101).

9 For the way in which the Egyptians perceived reality and represented it in visual art see the classic work by Schäfer (1986) with Appendix by Brunner-Traut on 'aspective' Egyptian art; see also Brunner-Traut (1996) and in $\operatorname{Ld\ddot {A}}(1977, \mathrm{I}: 474-488)$.

10 On Egyptian cosmography cf. Cornelius (1994b and 2002) with literature. 


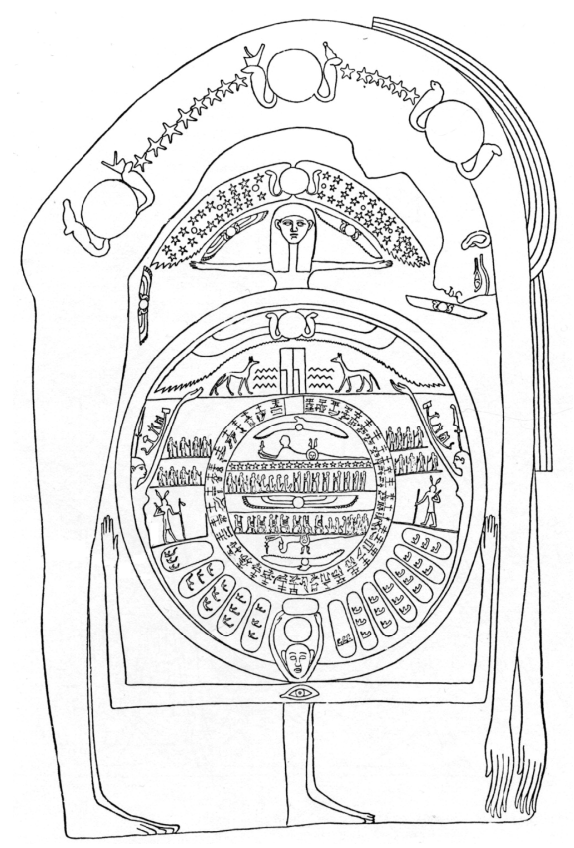

Fig. 2 Egyptian world (Keel 1977:Abb. 33)

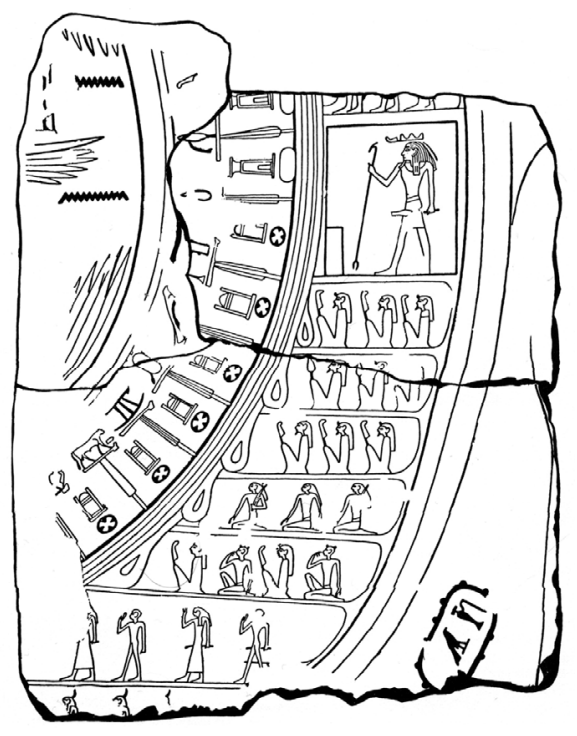

Below her is her father, the god Shu, who supports the sky; further down is her brother (and husband) the earth god Geb with feet and raised arms supporting a circle - the earth. Earth itself consists of circles or rings: the outer one is the Ocean, the inner one in the centre has what looks like Chinese letters, but these are the symbols of the 40 nomes (states) of Egypt. The 12 ovals with figures in them are the foreign countries. This is clearer on an older scene from the New Kingdom $\left(2^{\text {nd }}\right.$ half of the $2^{\text {nd }}$ millennium BCE) (Keel, 1977, Abb. 34) (see Figure 3). It shows the standards of the Egyptian states in the centre and in the outside ring is the god of the foreign lands with a feather and the hieroglyph sign for foreign land (Gardiner, 1964:488, N25). Below him are seated figures with feathers on their knees - here they represent subjugated foreign kings.

- First conclusion: The Egyptians perceived their country as the centre of the cosmos, the axis mundi, while the foreign lands formed the peri-

phery. This idea of the axis mundi occurs in many cultures - it could be Jerusalem (as we find on medieval Crusader maps), Rome or Mecca (Cornelius, 1998).

One of the oldest stories in the world - and which was very popular in ancient Egypt - is the tale of Sinuhe (Lichtheim, 1973:222ff.; cf. Loprieno, 1988:41ff.), who lived in exile in Palestine (Canaan) in the $20^{\text {th }}$ century BCE. Although the story is somewhat positive about Asians, it still is Egyptocentric. When Sinuhe returned to Egypt, he was shaven properly and all the dirt literally 'given back to the desert'; he was dressed properly and slept in a bed like a proper civilized Egyptian (Lichtheim, 1973:233; cf. Smith, 2003:29). Foreigners living in Egypt had to dress and behave like Egyptians. This included young foreign princes who were captured and taken to Egypt, where they were educated in the Egyptian lifestyle (Bianchi, 2004:114) - a custom known from later, especially British, colonial history.

Fig. 3 Egyptian world 2

(Keel 1977:Abb. 34) 


\section{Mapping and Representing the Neighbours of Egypt}

From the ancient 'mythological' map on the sarcophagus one can move to a map indicating Egypt's foreign neighbours (see Figure 1) with the names in hieroglyphs..$^{11}$ A clockwise tour of the countries around Egypt can be undertaken. Starting in the south there is Kush (Egyptian Kash), Nubia, in the present Sudan, and Tekhnu, that is Libya, to the west. Then crossing over to the Mediterranean there are the Greeks and the Greek islands, and Keftiu, the Egyptian name for the island of Crete (Helck, 1979). In Eastern Turkey or Anatolia is the great Empire of the Indo-European-speaking Hittites (Warburton, 2003), then Retjenu Syria and Palestine, and last but not the least the enigmatic land of Punt. It has still not been precisely identified, with some representations placing it in the eastern part of Africa or perhaps even Arabia (Glenister, 2008). All the names have at the end the same hieroglyphic sign -a determinative or taxogram - indicating the word-group. This is the hieroglyph for a hilly country or the desert - indicating 'foreign land' (khaset) (Gardiner, 1964:488, N25). It is found in the name of the well-known, but still enigmatic Hyksos, kheqau khasut 'rulers of foreign lands' ${ }^{12}$ In contrast, Egypt (Kemet/Black land) is written with the determinative for a town. This indicates that Egyptians regarded their part of the world as cultivated, ordered and civilized, while the other countries were not - only hills, rocks and sand. Some regions were not simply deserts in reality, but the symbolical stereotype prevailed. Although generic terms were used for foreigners in general, the Egyptians also distinguished between different groups of foreigners (O'Connor, 2003:155).

Foreigners are not only differentiated in terms of their names as shown on the map (Figure 1), but they are also distinguished in art. Four groups of peoples are indicated (Hornung, 1982, Abb. 120, cf. 123; Keel, 1977, Abb. 494) (see Figure 4): An Egyptian painted in redbrown; a light-skinned Asian with his thick beard and tasselled kilt; a black beardless Nubian with a large belt; and an exotic-looking Libyan with a goatee beard, tattooed and with feathers in his hair. The Egyptian is darker in complexion than the Asiatic and Libyan, but lighter than the Nubian. ${ }^{13}$ The fact that foreigners are depicted in the royal tombs reflects a positive attitude - foreigners also stood under the protection of the gods of Egypt.

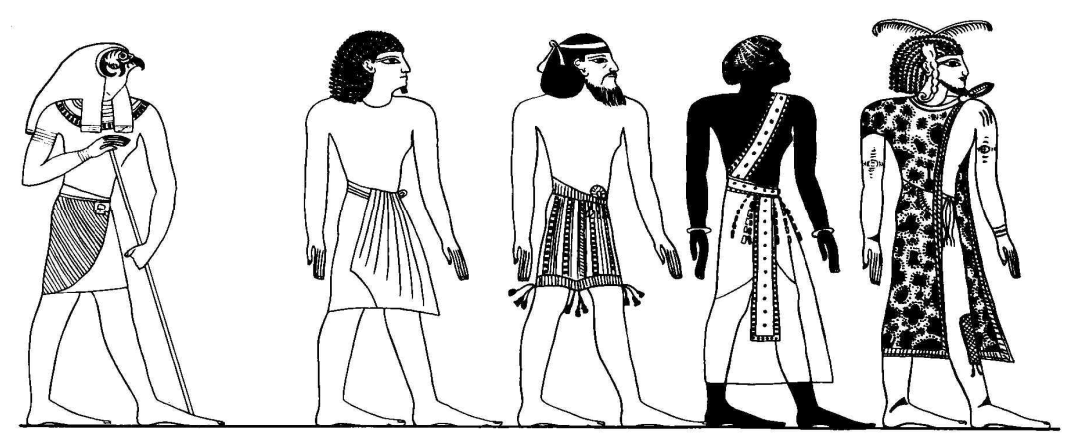

Fig. 4: Horus with Egyptian, Asian, Nubian and Libyan (Keel 1977:Abb. 494)

11 For detailed hieroglyphic names see Hannig \& Vomberg (1999:242-247); for the hieroglyphs in general see the classic studies by Gardiner (1964) and Wilkinson (1992).

12 'Foreign ruler' already occurs on a $19^{\text {th }}$ century BCE painting at Beni Hasan (Pritchard, 1969a, 3; Booth 2005:21; Keel, 1977, Abb. 308; Staubli, 1991:30ff., Abb. 15a-b). On the Hyksos see Redford (1992:98ff.) and the important information from Avaris (inter alia Bietak, 1996).

13 This brownish colour of the Egyptian is also found on painted statues of men, whereas the women are of a lighter colour. 
In the 'Great Hymn' from Amarna the god Aten is hailed:

$O$ sole god, like whom there is no other! Thou didst create the world according to thy desire, Whilst thou wert alone: All men, cattle, and wild beasts, Whatever is on earth, going upon (its) feet, And what is on high, flying with its wings. The countries of Syria and Nubia, the land of Egypt, Thou settest every man in his place, Thou suppliest their necessities: Everyone has his food, and his time of life is reckoned. Their tongues are separate in speech, And their natures as well; Their skins are distinguished, As thou distinguishest the foreign peoples (ANET, 1969:370; cf. Lichtheim, 1976,:98).

The Aten is the sole god and the creator of all living things, the foreign countries and the land of Egypt. He has given people separate countries, languages and appearances. This hymn reflects some sort of universalism, but it is idealistic and unique. ${ }^{14}$ However, in general the Egyptians thought peoples were not all created equal, or at least some were 'less equal' when compared to the Egyptians, as other sources inform us.

\section{Conquering and Subjugating the Wretched Foreigners (Order versus Chaos)}

The foreigners are also called 'wretched', the inhabitants of Asia are 'vile' and do not know god. ${ }^{15}$ The Hittites are also 'vile' (Lichtheim, 1976:64ff.). They are compared to the crocodile (Loprieno, 1988:24-25; Lichtheim, 1976:103-104), and against such people the Egyptians had to be protected. The one who prevents them from entering Egypt was the divine pharaoh, who maintained order: "to bar Asiatics from entering Egypt ... Then Order will return to its seat, while Chaos is driven away" (Lichtheim, 1973:143-144). The divinely ordained cosmic order, 'truth', also indicating justice - an abstract principle, but also a goddess - was indicated by the Egyptian concept maat (Assmann, 2006; Lichtheim, 1992; Wilkinson, 1992:36-37). The heart of the deceased was weighed on a scale against the feather or effigy of maat in order to determine whether it was pure (Seeber, 1976:Stadler, 2008). The king presented or offered effigies of the goddess Maat (ANEP, 1969:572; Keel, 1977, Abb. 379; Teeter, 1997). Maat stood in contrast to dis-order or chaos ('falsehood'), Egyptian isfet (Smith, 1994), which like the foreigner has to be driven away or kept at bay; the same applied to criminals.

The pharaoh kept disorder/chaos away by conquering the foreign enemy and for this reason political violence was legitimized (Assmann, 1995). There are examples of 'symbolic violence' (Müller-Wollermann, 2009), which were also represented in visual form. One of the oldest icons of pharaonic power is the 'smiting king', which goes back to 3000 BCE and persisted even after the Romans invaded Egypt (Keel, 1977, Abb. 397ff.; Hall, 1986). This served as an icon of violence against enemies (Assmann, 2008:28). The pharaoh grabs the enemy by the hair, lifts his weapon and is ready to smite him. ${ }^{16}$ This gesture, described as "the arm of my majesty is lifted to ward off evil", is mostly performed in the presence of a god, who guaranteed a victorious outcome by holding out a sword as a pledge (Keel, 1974, Abb. 22ff., 1977, Abb. 417a, Taf. XXI, 1999) (see Figure 5). When going into battle the pharaoh was supported by the gods (Cornelius, 1995). The king in his chariot is supported by the warrior god Monthu and the god shoots arrows into the enemy (Keel, 1977, Abb. 357). A scene from the famous battle of Kadesh (ca. 1287 BCE) depicts

14 In Amarna art the subjugated foreigners (discussed below) are still shown (O'Connor, 2003, Figs. 9:14-16).

15 Egyptian khezi. This is the same word which is used by Manetho when he describes the Hyksos (Redford, 1992:98-100). For the relations between Egypt and Asia cf. the classic study by Helck (1971), also Redford (1992); and on Egyptian military activities in Palestine see Hasel (1998).

16 On whether this was literally carried out, cf. Schulman (1987). 
pharaoh Ramses II as a giant taking on the mighty Hittite chariot force and defeating it (Keel, 1977, Abb. 405). In the same way that wild animals are hunted, so is the enemy hunted, in this case by the boy pharaoh Tutankh-Amen and the Nubians (Keel, 1977, Taf XVI). The Nubians, whom the pharaoh pursues in his chariot, look like ants against the gigantic king, but note also the contrast between the chaotic swarms of the Nubians (isfet= chaos) and the order (maat) represented by the divine ruler. After the battle is over, the pharaoh rides victoriously in his chariot with prisoners bound to his chariot as trophies, as with Amenhotep II (Keel, 1977, Abb. 138, cf. 405a) (see Figure 6). ${ }^{17}$

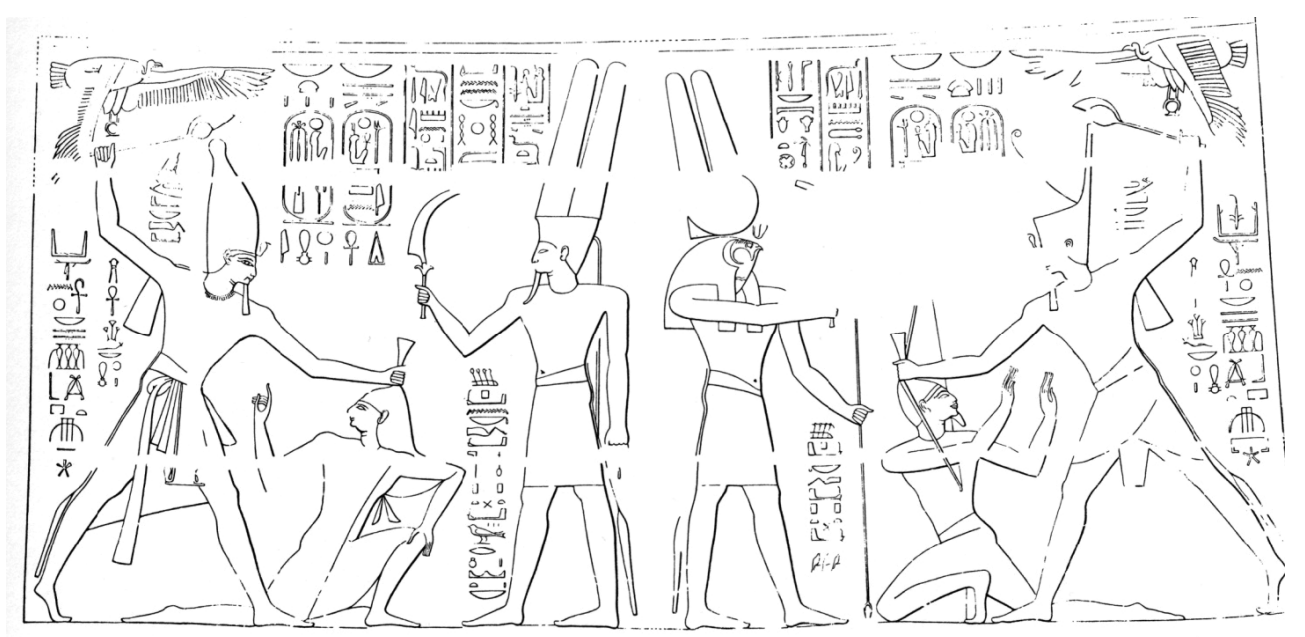

Fig. 5: Smiting the enemy (Keel 1977:Abb. 417a)

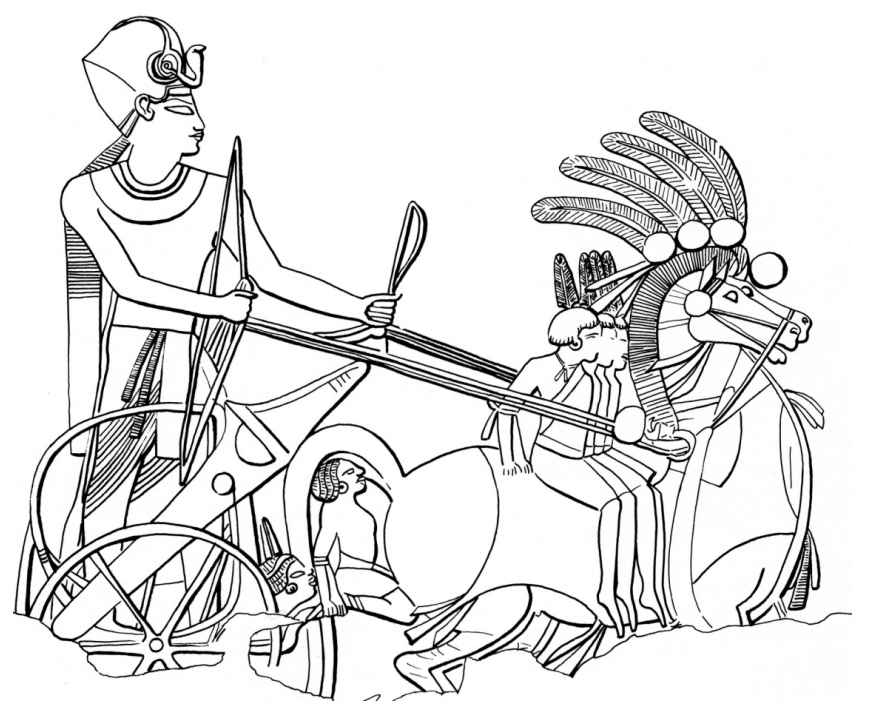

Fig. 6: Victorious pharaoh with prisoners (Keel 1977:Abb. 138)

17 This kind of display is well known from Roman triumphal processions, when the victorious emperor paraded the booty and prisoners from the foreign lands he conquered (Versnel, 1970). 


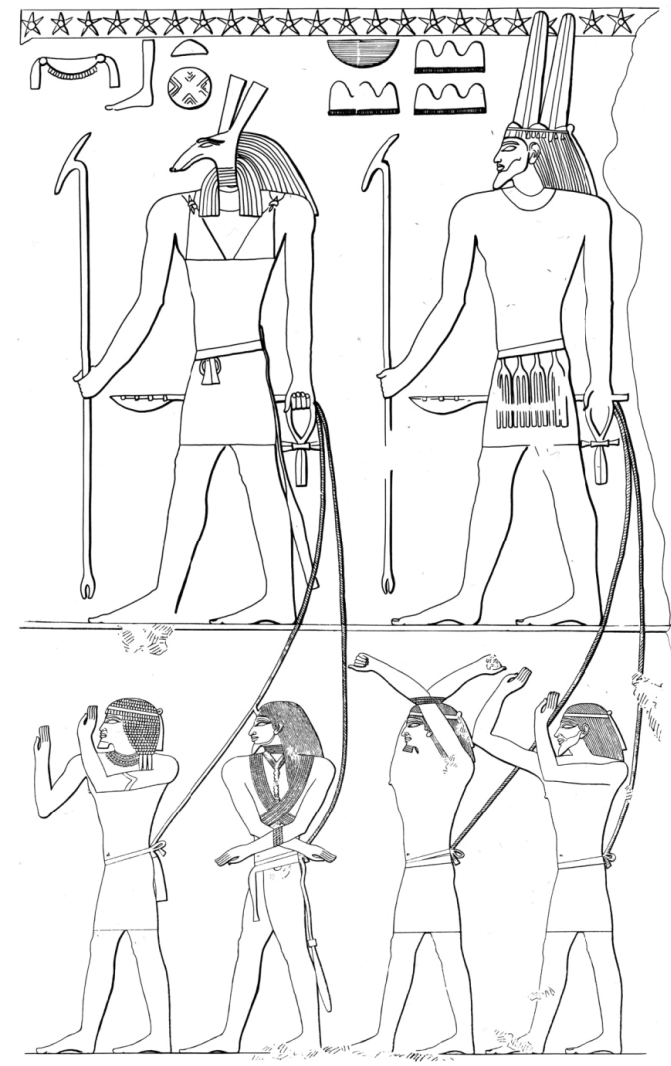

Fig. 7: Seth and Sopdu with foreign prisoners (Keel 1977:Abb. 406)

The Nubian prisoners have their arms tied behind their backs - as shown in the determinatives with the hieroglyphs for 'rebel', 'enemy' and 'Nubian' (Gardiner, 1964:443, A13; Wilkinson, 1992:18-19). This is, like the smiting king, a very ancient icon; graffiti from Gebel Sheikh Suleiman (Wilkinson, 1999:177-179, Fig. 5.3:2) in the Sudan go back to $3000 \mathrm{BCE}$ and show a prisoner with arms bound behind his back with a bow (the name for Kush, Ta-Sety 'land of the bow' (Gardiner, 1964:512, 619, Aa32/T10). It shows how very early on in Egyptian history the pharaohs had raided this region. ${ }^{18}$ A relief of SakhuRa 2480 BCE in the Egyptian collection in Berlin (ÄS 21782, Keel, 1977, Abb. 406) (see Figure 7) shows the god Seth and Sopdu (indicated as $n b$ khasut 'Lord of the foreign lands'; cf. Schumacher, 1988) with prisoners from Punt, Libya and Asia on leashes. The god Amen is also holding prisoners on leashes, indicated as bound prisoners by means of the names of the conquered cities in hieroglyphs (Keel, 1974, Abb. 26, 1977, Taf. XXII). Bound prisoners are shown in various visual media, such as on relief work and in art in miniature, and even on the decoration of a chariot of Tutankh-Amen (ANEP, 1969:8).

In addition to the term khaset, there is another term indicating foreigners - the pesdjet pedjwt or 'nine bows' (O'Connor, 2003:155), which included the Asians and Nubians

18 Cf. also the bound Syrian on a gaming piece from Abydos ca. 3000 BCE (Pritchard, 1969a:44). Bound prisoners are also shown in later times (e.g. the Persians, cf. Vittmann 2003:141 and 157). 

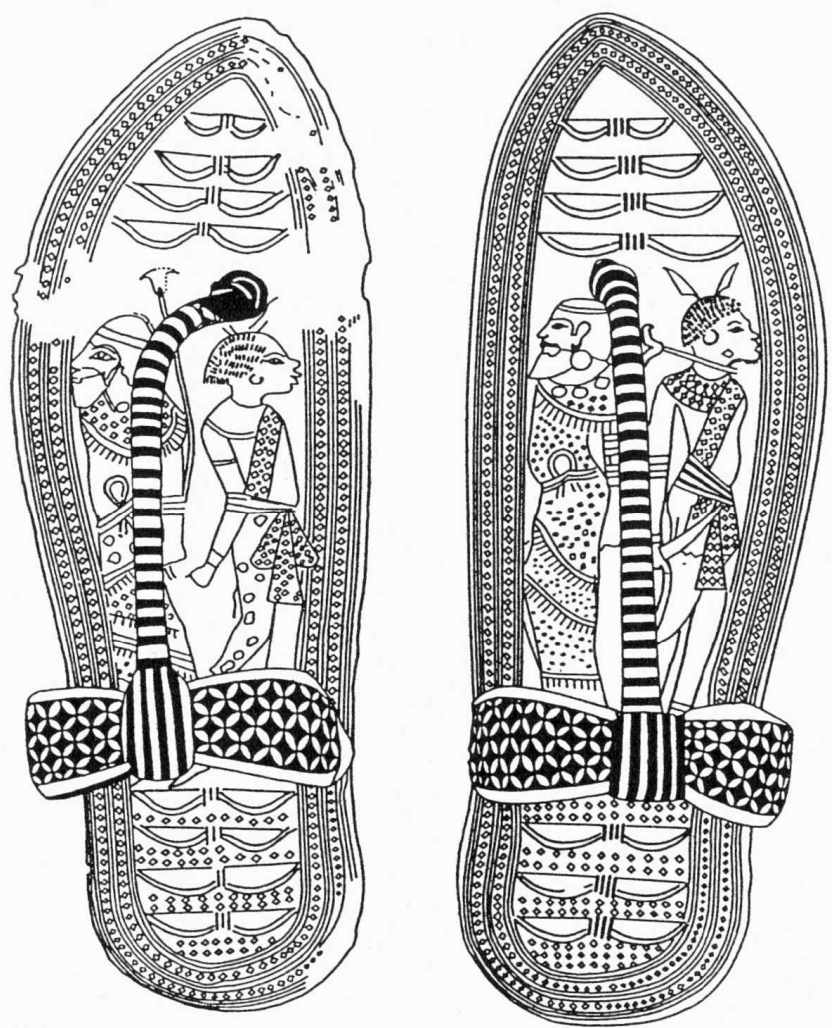

Fig. 8: Enemies on sandals (Schroer \& Staubli 1998:Abb. 91)

dealt with so far, and referred to as the 'totality' $(3 \times 3)$ of foreign lands. The nine bows (Gardiner, 1964:511, T10; Wilkinson, 1992:184-185) could also be depicted graphically as being trampled by the king, or as the young prince trampling on a footstool with enemies and bows depicted on it (Keel, 1977, Abb. 341-342a). This recalls a biblical text such as Psalm 110:1 “... until I make your enemies your footstool”. A physical example of such a footstool comes from the tomb of King Tut - which has depictions of enemies with bows (O'Connor \& Quirke, 2003, Fig. 1:5). Every time the king put his feet on the footstool, he was symbolically trampling his enemies. But even sandals have depictions of bound enemies (with bows!) on their soles and every time the pharaoh put on his sandals he symbolically trampled the enemy (Keel, 1982; Schroer \& Staubli, 1998:208ff., Abb. 91) (see Figure 8). Some amulets also depict feet trampling the enemy (Herrmann, 1994:298).

The bow is a symbol of power (Keel, 1990:27ff.; Wilkinson, 1991, 1992:185), but when it is broken, it is a symbol of defeat. This symbolism is demonstrated on a scene where Ramses attacks a city in Western Asia - he smites the ruler with his bow, but at the same time the conquered ruler snaps his bow to show he is defeated (Keel, 1977, Abb. 132a). Egyptian warships from the time of Ramses III 1190 BCE have battering rams which show a lioness devouring a foreign enemy (Landström, 1974, Abb. 347). These scenes make the point clear - the power of order (maat) over the enemy as chaos (isfet) was total! This raises the second conclusion: Egypt not only represented the centre 


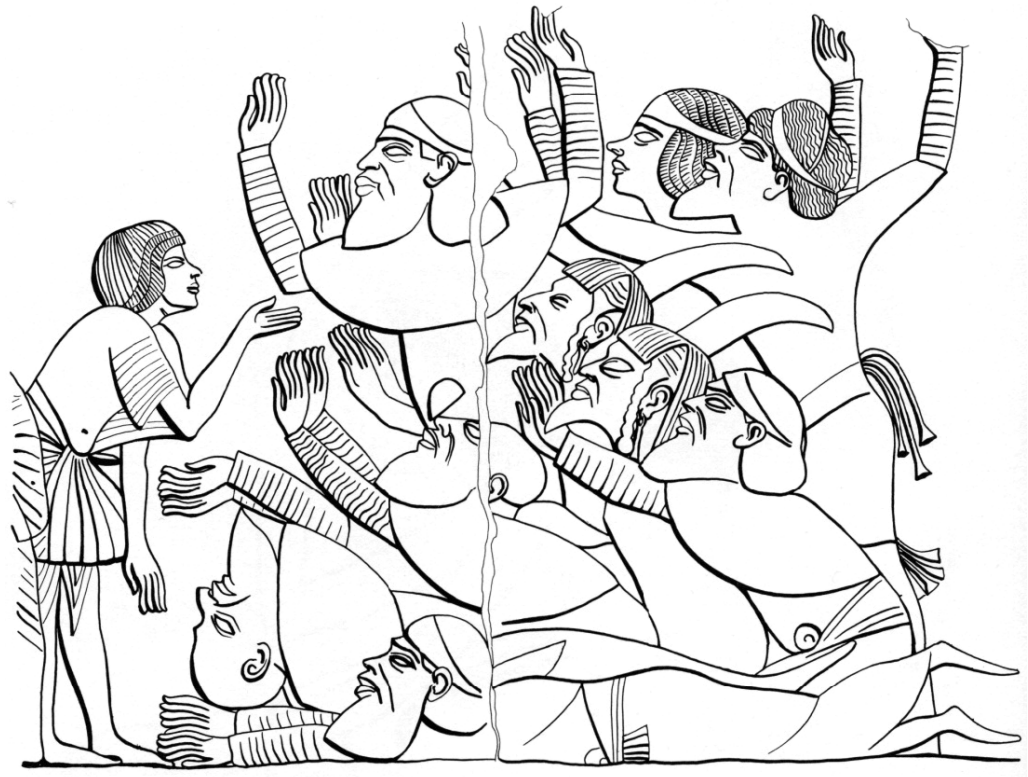

Fig. 9:

Prostrating

foreigners

(Keel 1977:

Abb. 429)

and the foreign lands the periphery, but Egypt stood for order against the chaos of the foreigners and this is why they had to be smitten and trampled on.

As a result of this, all foreigners must fall prostrate before the king of Egypt (Keel, 1977, Abb. 412), as also described in the Amarna letters (diplomatic correspondence between the pharaohs and foreign rulers): "At the feet of the king, my lord, seven times, seven times I fall down" (ANET, 1969:485). They are "dirt under the feet of the king" (ANET, 1969:484). The foreign lands bring tribute to the great king of Egypt (ANET, 1969:248-249) and there are many such depictions of tribute bearers (ANEP, 1969:45ff.; Keel, 1977, Abb. 408-409). Nubians are shown with stacks of gold, or ebony and ivory from Africa further to the south, but even tributes from Keftiu - that is the island of Crete are shown (Wachsmann, 1987).

A limestone relief from the tomb of Haremhab now in Leiden (ANEP, 1969:5; Haring, 2005, Fig. 1; Keel, 1977, Abb. 429; Martin, 1991, Fig. 49; Staubli, 1991:44ff.) shows prostrate foreigners (see Figure 9). ${ }^{19}$ Nine people are shown - they are the traditional enemies of Egypt as shown earlier: Asians, Libyans and a beardless Kushite. Their hands are in a gesture of begging, or as the text has it: "The princes of all the foreign countries ${ }^{20}$ come to beg life from him" (ANET, 1969:251). Some are crawling on their bellies, others are on their backs, again reminiscent of what is found in the Amarna letters: "At the feet of the king, my lord, seven times and seven times verily I fall, both prone and supine" (ANET, 1969:490).

19 Note that the scene forms part of a broader context with the royal pair (Staubli, 1991:45f., Abb. 30b).

20 kheqau khasut! 


\section{Case Studies: Kush, Libya and Punt}

A little more attention will be devoted to the relationship between the Egyptians and their brothers to the south - the Kushites or Nubians of the Sudan, ${ }^{21}$ a matter dealt with by Redford (2004) in From slave to pharaoh. The black experience of Ancient Egypt and Smith (2003) in Wretched Kush. The region south of Aswan stretching into the northern Sudan was called in Greek Aethiopia, from Aethiops 'burned' or 'black', but this area is not to be confused with the contemporary region or state of Ethiopia proper. The Nubians/ Kushites are sometime described in very degrading terms, as on a boundary stela of king Senusret /Sesotris III: "they cannot be trusted, they are not people (ni-remetju) one respects. They are wretches, craven-hearted" (Lichtheim, 1973:119; Loprieno, 1988:25). The Egyptians called themselves 'the people' remetju, the (proper) people.

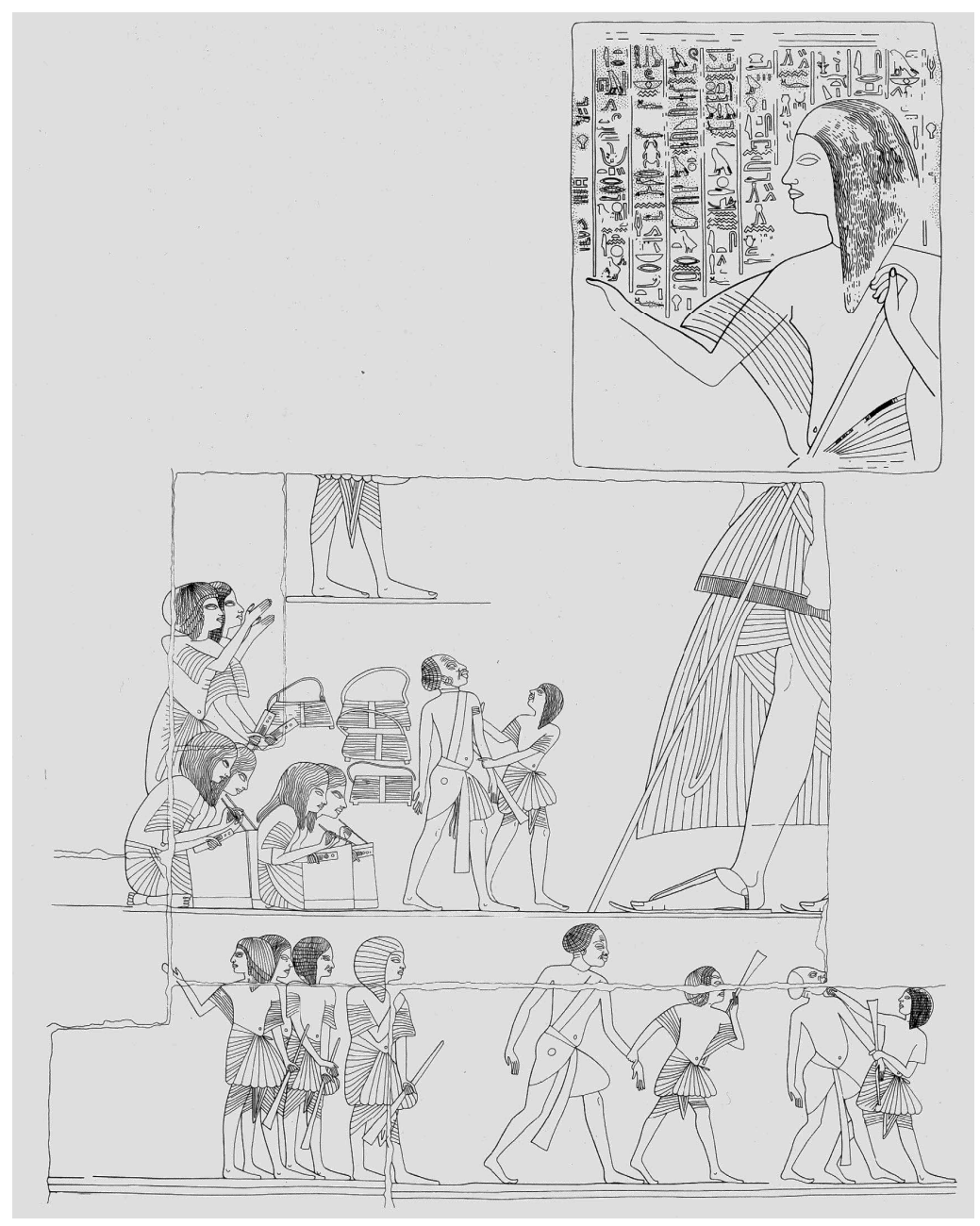

Fig. 10 Abusing Kushites (Martin 1991:Fig. 31)

21 Cf. Bonnet \& Valbelle (2006); Morkot (2000). 
However, in contrast the Nubians are referred to as ni remetju, non-people, nonhumans, or savages (Wilson, 1977:33). Therefore, they are not treated with dignity and need not be respected. In the text of Ipuwer (Lichtheim, 1976:151-152; Loprieno, 1988:29) there is a complaint that the world is so topsy-turvy that foreigners have become 'people'. The Greeks called nations who did not speak Greek 'Barbarians' (cf. Coleman \& Walz, 1997). The language of the Nubians is also described as 'unintelligible, like the jabbering of baboons' (Smith, 2003:27).

Another set of unique sources are reliefs from the tomb of Haremhab at Saqqarah, commander-in-chief in the time of Tutankh-Amen and later pharaoh himself (Martin, 1991, Fig. 31, cf.: 67ff.) (see Figure 10). The decoration of the south-eastern corner of the inner courtyard shows episodes of his career. Rows of prisoners of war are paraded in front of the general. There are beardless Nubians, Libyans with their goatee beards, and Asians with their thick beards. Some details show the way in which some of these POWs are treated. A smaller Egyptian guard armed with a stick is pulling on the arm of an Asian. Another one is admonishing a Nubian. ${ }^{22}$ A guard leads a Nubian in front of the great general himself shown as a giant to indicate his power, while scribes record everything. A guard even goes further and punches a Nubian on the jaw. These are quite vivid scenes of the way in which the Egyptians treated their fellow Africans. A group of Nubians await transportation either to labour camps or other places of confinement - this scene reminds us of later times when thousands of African slaves were taken from their homes to work for others in foreign lands. There is a relief in Bologna in Italy also showing Nubian captives with their Egyptian guards and a scribe ${ }^{23}$ - the different actions of the three guards speak for themselves.

There was no love lost between the Egyptians and the Libyans (Hölscher, 1955; Leahy, 1990), who are also described as 'wretched/vile' on a stela of Merneptah (Lichtheim, 1976:74ff.; Loprieno, 1988:38). From the time of Ramses III (Edgerton \& Wilson, 1936) there are descriptions of his wars against them. The hands of the Libyan captives were cut off, but also other body parts; the Great Karnak inscription of Merneptah (Breasted, 1906, III:247) describes the army returned, their asses "laden with the uncircumcised phalli of the enemy of Libya together with the hands of every other country that was with them." This is also depicted in visual form in the Medinet Habu temple of Ramses III (Schulz \& Seidl, 1998:368).

The final case study deals with the enigmatic land of Punt (Glenister, 2008; Harvey, 2003; Meeks, 2003). Trading expeditions and travelogues describe this land, and it is depicted in the reliefs of the female pharaoh Hatshepsut in her mortuary temple at Deir elBakhri (Naville, 1898). There are ships laden with exotic products; even their houses are shown, as are the Prince of Punt and his Queen (Glenister, 2008, Fig. 5.11; Naville, 1898, Pl. 69) (see Figure 11). She even became a caricature in later Egyptian graffiti and popular art. These scenes could perhaps be described as some of the earliest examples of ethnography.

In the nearly 3000 years of recorded history of Egypt, under the Pharaohs, Egypt did not only conquer and rule over foreign lands in Africa and Asia, ${ }^{24}$ but during certain periods the tables were turned and there were incursions into Egypt by foreigners (Leahy in $O E A E$,

\footnotetext{
A familiar gesture! At the Kolleg Heinrich Bedford-Strohm mentioned finger-pointing! Online at http://www.comune.bologna.it/museoarcheologico/collezio/collez.htm.

24 O’Connor (2003, Fig. 9:9) shows a papyrus where Libyans attack an Egyptian. This is rare because usually Egyptians are shown attacking foreigners.
} 


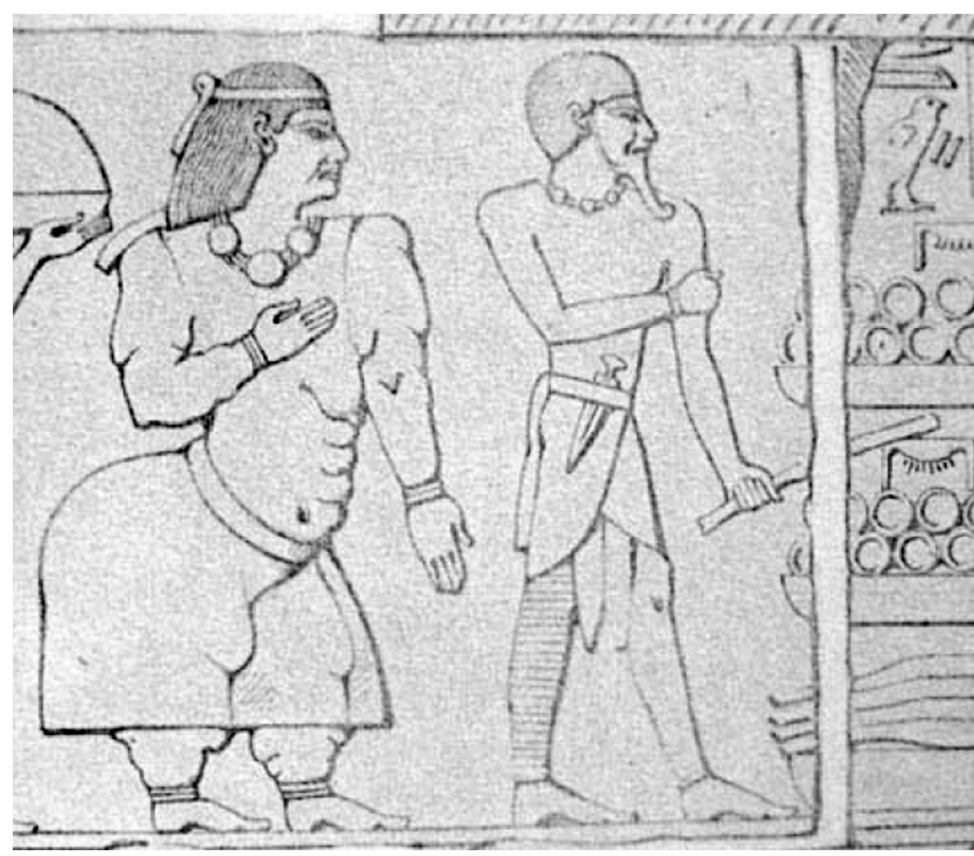

Fig. 11: Queen and prince of Punt (Naville 1898: Pl. 69)

2001, 1:548ff.). Such foreigners ruled over ancient Egypt (see Figure 12): Hyksos, Libyans, Kushites, Assyrians, Babylonians, Persians, Greeks and Romans. After the glory of the New Kingdom, the Imperial Period during the $2^{\text {nd }}$ part of the $2^{\text {nd }}$ millennium BCE, when Egypt ruled over Kush and the Levant, Egypt was constantly under foreign rule. Egypt was indeed a 'broken reed' as the prophet Isaiah (36:6) describes it. In the first part of the first millennium there were the Libyan dynasties $\left(21\right.$ and 22). The $25^{\text {th }}$ Kushite Dynasty was of Nubian stock, the so-called 'Black Pharaohs'. Then Egypt became part of the massive Assyrian, Babylonian and Persian empires, followed by the Greeks (Ptolemies), before it was conquered and ruled by Rome.

\section{FOREIGN RULERS IN EGYPT}

\begin{tabular}{|r|c|c|l|}
\hline & Date & Dynasty & Foreign Rulers \\
\hline 2000 & & & \\
& $1650-1550 \mathrm{BC}$ & 15 & Hyksos \\
\hline 1000 & $1000-715$ & $21-22$ & Libyan \\
& $715-657$ & 25 & Kushite \\
& & & Assyrian-Babylonian \\
& $525-323$ & 27 & Persian \\
\hline & $305-30$ & & Greek-Ptolemaic \\
\hline 0 & $30-395 \mathrm{AD}$ & & Roman \\
\hline
\end{tabular}

Fig. 12: Table of foreign rule over Egypt (I. Cornelius) 


\section{Conclusions}

Were the ancient Egyptians xenophobic? Were they racists? One should be careful to apply racial terms to the ancient world (Bahrani, 2006; Smith, 2003; OEAE, 2001:27ff., 111ff.). As shown by the African American scholar Snowden (1983; 1993), this was a time Before color prejudice. To the Egyptian mind, anyone not Egyptian or living in Kemet was regarded as a 'barbarian'. Skin colour or race was not an issue in antiquity (see Figure 4 which demonstrates skin colour to be more symbolic than racial), but this does not mean that there was no discrimination, as shown by Redford (2004:9). For example, a decree of Pepy I (ca. 2325 BCE) prohibited Nubians from harvesting certain lands and they - like other foreigners - were not allowed to enter Egyptian temples. The Egyptians treated foreigners like animals; some texts even describe foreigners as animals (Loprieno, 1988:26ff.). The sources have shown the harsh way in which the Egyptians treated people from Asia. The Nubians - their African brothers to the south - were physically manhandled. The Libyans to the west were subjected to degrading treatment.

However, it is important to give the total picture. Loprieno (1988) distinguished between topos ${ }^{25}$ and mimesis. Topos refers to a generalising stereotype of the foreign savage who should be conquered, while mimesis refers to a more realistic positive attitude, where Egyptians interacted with foreigners. Booth (2005) collected material on foreigners in Egyptian society and 'non-stereotypical' artistic representations. Smith (2003) also took up this perspective and argued that it was only according to Egyptian (pharaonic) ethnic ideology that the Kush people were considered 'wretched'. Ample examples of the harsh treatment of foreigners have been given. But there is also a flip side to the coin. Foreigners were accepted into Egyptian society, but under certain conditions, such as adopting Egyptian customs. Nubians served as mercenaries in the Egyptian army, as crack bowmen, as depicted in tomb models. Smith (2003:23) refers to mixed marriages between Nubian mercenaries and Egyptian women as shown on stelae. A stela from Amarna - now in the Egyptian museum in Berlin (ÄS 14122 in Booth, 2005:36; Haring, 2005:168-169, Fig. 2) shows a foreign Asian mercenary (Asian name, clothing and spear) with his wife, but she is dressed like an Egyptian (as is the servant), although her name is not Egyptian. In Genesis 39 and further is the tale of Joseph, the Hebrew slave who became viceroy of Egypt and married Asenath, the daughter of an Egyptian priest of the sun god of Heliopolis. ${ }^{26}$ The vizier Aper-El (Zivie, 2008; cf. Hoffmeier, 1997:94ff.), with a Semitic name, is another example of an acculturated foreigner (Smith in OEAE, 2001:114). Some pharaohs married foreign women as part of international diplomacy (Helck, 1971:351; Pintore, 1978), as in the case of King Solomon with his 1000 wives (1 Kgs 11:1-3).

Foreign words and deities, especially from the Levant (Syro-Palestine), were introduced into Egypt and worshipped by pharaohs (Baal, Reshep, Anat, Astarte) and commoners (Qedeshet). ${ }^{27} \mathrm{~A}$ unique case is Ramses II and the goddess Anat, whom he called 'mother' (Cornelius, 2008:85).

O'Connor (2003) differentiates between actuality, ideology and belief.

26 On the Egyptian background of these stories and the possible Egyptian origin of the names see Vergote (1959), but Redford (1970, 1992:422ff.) is more critical. More positive ('maximalistic') are Hoffmeier (1997) and Kitchen (2003).

27 Cf. Schneider (1992); Zivie-Coche (1994) and for foreign deities Cornelius (1994a, 2008) and now Tazawa (2009). 
These are some images from an ancient African civilization, Egypt - which, according to the historian Toynbee, had no predecessor and no successor. The brief for this Alexander von Humboldt Kolleg mentioned terms and concepts that can be linked with ancient Egypt. 'Slavery' - the Egyptians got their slaves from Nubia and Asia. 'Colonial rule' - Egypt ruled Nubia and Palestine as colonies. 'Unfair trade' - there was a lot of unfair trade: the ancient Egyptians did not only trade non-aggressively, as with the land of Punt, but they also took what they needed through conquest and tribute from abroad, especially the gold of Nubia. When one thinks about ancient Egypt one should not be seduced by the magnificent buildings still standing, the literature, the achievements - it was also a very 'inhumane' society, ruled by a God-King who treated 'the other' without dignity. In any case, this is the topos/ideology which some of the sources communicate. ${ }^{28}$

\section{BIBLIOGRAPHY}

Allen, JP 2003. The Egyptian concept of the world. In D O'Connor \& S Quirke (eds.), Mysterious lands (pp. 23-30). London: UCL.

Allen, RE (ed.) 1990. The Concise Oxford English Dictionary of Current English. Oxford: Oxford University Press.

ANEP $=$ Pritchard, JB (ed.) 1969. Ancient Near Eastern Pictures. Relating to the Old Testament. Princeton: Princeton University Press.

ANET $=$ Pritchard, JB (ed.) 1969. Ancient Near Eastern Texts. Relating to the Old Testament. Princeton: Princeton University Press.

Assmann, J 1995. Ägypten und die Legitimierung des tötens: ideologische Grundlagen politischer Gewalt im alten Ägypten. In H von Stietencron, \& J Rüpke (Hrsg.). Töten im Krieg (pp. 57-85). Freiburg/München: Karl Alber.

Assmann, J 1996. Zum Konzept der Fremdheit im alten Ägypten. In M Schuster (Hrsg.). Die Begegnung mit dem Fremden (pp. 77-99). Stuttgart: Teubner.

Assmann, J 2006. Ma'at. Gerechtigkeit und Unsterblichkeit im Alten Ägypten, München: Beck.

Assmann, J 2008. Of gods and men: Egypt, Israel, and the rise of Monotheism. Wisconsin: University of Wisconsin Press.

Bahrani, Z 2006. Race and Ethnicity in Mesopotamian Antiquity. World Archaeology, $38(1), 48-59$.

Bianchi, RS 2004. Daily life of the Nubians. Westport: The Greenwood Press.

Bietak, M 1996. Avaris: The capital of the Hyksos. London: British Museum.

Bonnet, C \& Valbelle, D 2006. The Nubian Pharaohs. Black kings on the Nile. Cairo: American University in Cairo Press.

Booth, C 2005. The role of foreigners in Ancient Egypt (BAR S1426). Oxford: Archaeopress.

Breasted, JH 1906. Ancient records of Egypt. Chicago: University Press.

28 In this regard it should be kept in mind that iconography, for example, is not an eyewitness, nor a window into the past, but remains valuable testimony in its own right, as Uehlinger (2007) argues. 
Bresciani, E 1997. Foreigners. In S Donadoni (ed.). The Egyptians (pp. 221-251). Chicago: University of Chicago Press.

Brunner-Traut, E 1996. Frühformen des Erkennens: Aspektive im alten Ägypten. Darmstadt: Wissenschaftliche Buchgesellschaft.

Cartledge, P 1993. The Greeks. A portrait of Self and Others. Oxford: University Press.

Coleman, JE \& Walz, CA (eds.) 1997. Greeks and Barbarians. Bethesda (MD): CDL.

Cornelius, I 1994a. The iconography of the Canaanite Gods Reshef and Ba'al. Late Bronze and Iron Age I Periods (c 1500-1000 BCE) (OBO 140). Fribourg: University Press.

Cornelius, I 1994b. The visual representation of the world in the Ancient Near East and the Hebrew Bible. JNSL, 20(2), 193-218.

Cornelius, I 1995. The iconography of divine war in the pre-Islamic Near East: A survey. JNSL, 21(1), 15-36.

Cornelius, I 1998. How maps 'lie'. Some remarks on the ideology of ancient and 'scriptural' maps. JNSL, 24(1), 217-230.

Cornelius, I 2002. Landkarten (antike). In HD Betz (ed.). Religion in Geschichte und Gegenwart Band 5 (pp. 61-63) (Handwörterbuch für Theologie und Religionswissenschaft) 4th edition. Tübingen: Mohr Siebeck.

Cornelius, I 2008. The many faces of the goddess. The iconography of the Syro-Palestinian goddesses Anat, Asherah, Astarte and Qedeshet c. 1500-1000 BCE (OBO 204). Fribourg: Academic Press.

Edgerton, WF \& Wilson, JA 1936. Historical Records of Ramses III: The Texts in Medinet $\mathrm{Habu}$ (SAOC 12). Chicago: University Press.

Forbes, D 2005. The Others. KMT 16(1), 66-73.

Forman, W \& Quirke, S 1996. Hieroglyphs \& the Afterlife in Ancient Egypt. London: Opus.

Fried, E 2008. From Xeno-Philia to Phobia - Jewish encounters with the Other. In Y Levin (Ed.). A time of change. Judah and its neighbours in the Persian and Early Hellenistic Periods (pp. 179-204). London: Continuum.

Gardiner, AH 1964. Egyptian Grammar. Oxford: Griffith Institute.

Glenister, C 2008. Profiling Punt: Using trade relations to locate 'God's Land'. Unpublished master's thesis, University of Stellenbosch, Stellenbosch, Western Cape, South Africa. Retrieved October 30, 2010, from https://scholar.sun.ac.za/handle/10019.1/1564

Haas, V 1980. Die Dämonisierung des Fremden und des Feindes im Alten Orient. Rocznik Orientalistyczny XLI(2), 37-44.

Hall, ES 1986. The pharaoh smites his enemies: A comparative study. München: Deutscher Kunstverlag.

Hannig, R \& Vomberg, P 1999. Wortschatz der Pharaonen in Sachgruppen: Kulturhandbuch Ägyptens. Mainz: Von Zabern.

Haring, R 2005. Occupation: Foreigner. Ethnic difference and integration in Pharaonic Egypt. In W Van Soldt, RK Kalvelagen \& D Katz (eds.). (2005). Ethnicity in Ancient Mesopotamia (PIHANS 102) (pp. 163-172). Leiden: Nederlands Instituut voor het Nabije Oosten.

Harvey, SP 2003. Interpreting Punt: Geographic, cultural and artistic landscapes. In D O’Connor \& S Quirke (eds.), Mysterious lands (pp. 81-91). London: UCL. 
Hasel, M 1998. Domination and resistance: Egyptian military activity in the Southern Levant, ca. 1300-1185 BC. Leiden: Brill.

Helck, W 1964. Die Ägypter und die Fremden 15, 103-114.

Helck, W 1971. Die Beziehungen Ägyptens zu Vorderasien im 3. und 2. Jahrtausend v. Chr. 2. verb. Aufl. Wiesbaden: Harrassowitz.

Helck, W 1979. Die Beziehungen Ägyptens und Vorderasiens zur Ägäis bis ins 7. Jahrhundert v. Chr. (Erträge der Forschung 120). Darmstadt: Wissenschaftliche Buchgesellschaft.

Herrmann, C 1994. Ägyptische Amulette aus Palästina/Israel (OBO 138). Freiburg (Schweiz): Universitätsverlag.

Hoffmeier, JK 1997. Israel in Egypt: The evidence for the authenticity of the Exodus Tradition. New York: Oxford University Press.

Hölscher, W 1955. Libyer und Ägypter. Glückstadt: JJ Augustin.

Hornung, E 1982. Tal der Könige. Die Ruhestätte der Pharaonen. Zürich: Artemis.

Keel, O 1974. Wirkmächtige Siegeszeichen im Alten Testament: Ikonographische Studien zu Jos. 8, 18-26; Ex. 17, 8-13; 2. Kön. 13, 14-19 und 1.Kön. 22, 11 (OBO 5). Fribourg: Fribourg University Press.

Keel, O 1977. Die Welt der altorientalischen Bildsymbolik und das Alte Testament. Zürich: Benziger.

Keel, O 1982. Symbolik des Fusses im Alten Testament und seiner Umwelt. Orthopädische Praxis, 18, 530-538.

Keel, O 1990. Der Bogen als Herrschaftssymbol. In O Keel, M Shuval \& C Uehlinger (eds.). Studien zu den Stempelsiegeln aus Palästina/Israel (OBO 100) (pp. 27-65). Fribourg: University Press.

Keel, O 1999. Powerful symbols of victory - the parts stay the same, the actors change. JNSL 25(2), 205-240.

Kitchen, KA 2003. On the reliability of the Old Testament. Grand Rapids: Eerdmans.

Landström, B 1974. Die Schiffe der Pharaonen: Ältagyptische Schiffsbaukunst von 4000 bis 600 v.Chr. München: Bertelsmann.

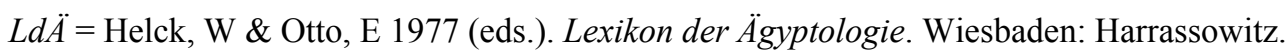

Leahy, A (ed.) 1990. Libya and Egypt c. 1300-750 BC. London: SOAS.

Leahy, A 1995. Ethnic diversity in Ancient Egypt. In J Sasson (ed.). Civilizations of the Ancient Near East (pp. 225-234). New York: Scribner.

Lichtheim, M 1973. Ancient Egyptian Literature. Vol. I. London: University of California.

Lichtheim, M 1976. Ancient Egyptian Literature. Vol. II. London: University of California.

Lichtheim, M 1992. Maat in Egyptian Autobiographies and Related Studies (OBO 120). Fribourg: University Press.

Liverani, M 1990. Prestige and interest: International relations in the Near East ca. 1600-1100 BC. Sargon: Tipografia Poligrafica Moderna.

Loprieno, A 1988. Topos und Mimesis. Zum Ausländer in der ägyptischen Literatur (Ägyptologische Abhandlungen 48). Wiesbaden: Harrassowitz.

Louw, DJ (n.d.) Ubuntu: An African assessment of the religious other. Retrieved October 30, 2010, from http://www.bu.edu/wcp/Papers/Afri/AfriLouw.htm.

Martin, GT 1991. The hidden tombs of Memphis. London: Thames and Hudson. 
Meeks, D 2003. Locating Punt. In D O’Connor \& S Quirke (eds.), Mysterious lands (pp. 53-80). London: UCL.

Meyer, E 1913. Bericht über eine Expedition nach Ägypten zur Erforschung der Darstellungen der Fremdvölker. Berlin.

Müller-Wollermann, R 2009. Symbolische Gewalt im Alten Ägypten. In M Zimmerman (Hg.). Extreme Formen von Gewalt in Bild und Text des Altertums (Münchner Studien zur Alten Welt 5) (pp. 47-64). München: Herbert Utz.

Morkot, R 2000. The Black Pharaohs: Egypt's Nubian Rulers. London: Rubicon.

Naville, E 1898. The Temple of Deir el-Bahri. Vol. 3. London: Egyptian Exploration Fund.

$O E A E=$ Redford, DB (ed.) 2001. The Oxford Encyclopedia of Ancient Egypt. Oxford: Oxford University Press.

O'Connor, D 2003. Egypt's views of 'others'. In J Tait (ed.). 'Never had the like occurred': Egypt's view of its past (pp. 155-185). London: UCL.

O’Connor, D \& Quirke, S (eds.) 2003. Mysterious lands. London: UCL.

O’Connor, D \& Quirke, S 2003. Introduction: Mapping the unknown in Ancient Egypt. In D O’Connor \& S Quirke (eds.), Mysterious lands (pp. 1-21). London: UCL.

Pintore, F 1978. Il matrimonio interdinastico nel Vicino Oriente durante i secoli XV-XIII. Roma: Ist. per l'Oriente, Centro per le Antichità e la Storia dell'Arte del Vicino Oriente.

Pongratz-Leisten, B 2001. The other and the enemy in the Mesopotamian conception of the world. In RM Whiting, (ed.), Mythology and Mythologies. Methodological approaches to intercultural influences (Melammu Symposia 2) (pp. 195-231). Helsinki: The Neo-Assyrian Text Corpus Project.

Poo, M 2005. Enemies of civilization. Attitudes toward foreigners in Ancient Mesopotamia, Egypt, and China. Albany: State University of New York Press.

Redford, DB 1970. A study of the biblical story of Joseph. Leiden: Brill.

Redford, DB 1992. Egypt, Canaan, and Israel in ancient times. Princeton \& New Jersey: Princeton University Press.

Redford, DB 2004. From slave to Pharaoh. The black experience of Ancient Egypt. Baltimore: Johns Hopkins University Press.

Schäfer, H 1986. Principles of Egyptian Art. Oxford: Griffith Institute.

Schneider, T 1992. Asiatische Personennamen in ägyptischen Quellen des Neuen Reiches (OBO 114). Fribourg: Fribourg University Press.

Schneider, T 2003. Foreign Egypt: Egyptology and the concept of cultural appropriation. Ägypten und Levante, 13, 155-161.

Schneider, T 2010. Foreigners in Egypt. In W Wendrich (ed.). Egyptian Archaeology (pp. 141-163). Oxford: Blackwell Publishing, 141-163.

Schroer, S \& Staubli, T 1998. Die Körpersymbolik der Bibel. Darmstadt: WB.

Schulman, AR 1987. Ceremonial Execution and Public Rewards. Some Historical Scenes on New Kingdom Private Stelae (OBO 75). Fribourg: University Press.

Schulz, RS \& Seidel, M (eds.) 1998. Egypt: The World of the Pharaohs. Cologne: Könemann.

Schumacher, IW 1988. Der Gott Sopdu, der Herr der Fremdländer (OBO 79). Fribourg: University Press. 
Seeber, C 1976. Untersuchungen zur Darstellung des Totengerichts im Alten Ägypten (Münchner Ägyptologische Studien 35). München: Deutscher Kunstverlag.

Shaw, I (ed.) 2000. The Oxford History of Ancient Egypt. Oxford: Oxford University Press.

Smith, H 1994. Ma'et and Isfet. BACE, 5, 67-88.

Smith, ST 2003. Wretched Kush: Ethnic identity in Egypt's Nubian Empire. London: Routledge.

Snowden, FM 1983. Before color prejudice. Harvard: Harvard University Press.

Snowden, FM 1993. Images and attitudes. Ancient views of Nubia and the Nubians. Expedition, 35(2), 40-50.

Stadler, MA 2008. Judgment after death (Negative Confession). In J Dieleman \& W Wendrich (eds.), UCLA Encyclopedia of Egyptology. Los Angeles UCLA Retrieved October 30, 2010, from http://repositories.cdlib.org/nelc/uee/1013

Staubli, T 1991. Das Image der Nomaden (OBO 107). Fribourg: Fribourg University Press.

Sundermeier, T 1992. Die Religionen und die Fremden. In T Sundermeier (ed.), Den Fremden wahrnehmen. Bausteine für eine Xenologie (Studien zum Verstehen fremder Religionen 5) (pp. 186-201). Gütersloh: Gütersloher Verlagshaus Gerd Mohn.

Tazawa, K 2009. Syro-Palestinian deities in New Kingdom Egypt. The hermeneutics of their existence (BAR S1964). Oxford: Archaeopress.

Teeter, E 1997. The Presentation of Maat: Ritual and legitimacy in Ancient Egypt (SAOC 57). Chicago: Chicago University Press.

$T W A T=$ Botterweck, GJ, Ringgren, H \& Fabry, H-J (eds.) 1984. Theologisches Wörterbuch zum Alten Testament IV. Stuttgart: Kohlhammer.

Uehlinger, C 2007. Neither eyewitnesses, nor windows to the past, but valuable testimony in its own right. Remarks on iconography, source criticism, and ancient data processing. In H Williamson (ed.), Understanding the history of Ancient Israel. Proceedings of the British Academy 143 (pp. 173-228). Oxford: Oxford University Press.

Van der Merwe, W 1996. Philosophy and the multi-cultural context of (post)apartheid South Africa. Ethical perspectives, 3(2), 1-15.

Van Soldt, W, Kalvelagen, RK \& Katz, D (eds.) 2005. Ethnicity in Ancient Mesopotamia (PIHANS 102). Leiden: Nederlands Instituut voor het Nabije Oosten.

Vergote, J 1959. Joseph en Égypte: Genèse chap. 37-50 à la lumière des études égyptologiques rećentes. Louvain: Publications Universitaires.

Versnel, H 1970. Triumphus: an Inquiry into the origin, development and meaning of the Roman Triumph. Leiden: Brill.

Vittmann, G 2003. Ägypten und die Fremden im ersten vorchristlichen Jahrtausend. Mainz: Von Zabern.

Warburton, D 2003. Love and war in the Late Bronze Age: Egypt and Hatti. In R Matthews \& C Roemer (eds.). Ancient Perspectives on Egypt (pp. 75-100). London: UCL.

Wachsmann, S 1987. Aegeans in the Theban Tombs. Leuven: Uitgeverij Peeters.

Wilkinson, RH 1991. The representation of the bow in the art of Egypt and the Ancient Near East. JANES, 20, 83-99. 
Wilkinson, RH 1992. Reading Egyptian art. A hieroglyphic guide to Ancient Egyptian painting and sculpture. London: Thames \& Hudson.

Wilkinson, TAH 1999. Early dynastic Egypt. London: Routledge.

Wilson, JA 1977. Egypt. In HA Frankfort, HA Groenewegen-Frankfort, JA Wilson, T Jacobsen \& WA Irwin (eds.). The intellectual adventure of Ancient Man. An Essay on Speculative Thought in the Ancient Near East (pp. 29-122). Chicago: Phoenix.

Zehnder, M 2005. Umgang mit Fremden in Israel und Assyrien (BZAW 168). Stuttgart: Kohlhammer.

Zivie, A 2008. The lost tombs of Saqqara. Cairo: AUC.

Zivie-Coche, C 1994. Dieux autres, dieux des autres: Identite culturelle et alterite dans l'Egypte ancienne. In I Alon, I Gruenwald \& I Singer (eds.). Concepts of the other in Near Eastern religions (Israel Oriental Studies 14) (pp. 39-80). Leiden: Brill Academic Publishers. 